DRAFT

Please do not quote

without permission

\title{
Operating Performance of Banks Among Asian Economies: An International and Time Series Comparison
}

\author{
Simon H. Kwan \\ Federal Reserve Bank of San Francisco
}

January, 2002

\begin{abstract}
After controlling for loan quality, liquidity, capitalization, and output mix, per unit bank operating costs are found to vary significantly across Asian countries and over time. Further analysis reveals that the country rankings of per unit labor and physical capital costs are highly correlated, suggesting that there exist systematic differences in bank operating efficiency across Asian countries. However, this measure of operating efficiency is found to be unrelated to the degree of openness of the banking sector.

Asian bank operating costs were found to decline from 1992 to 1997, indicating that banks were improving their operating performance over time. Since 1997, the run-up in operating costs coincided with the Asian financial crisis, suggesting that banks were incurring additional costs in dealing with their problem loans while output was declining simultaneously.

Moreover, the labor cost share is found to decline significantly between 1997 and 1999 , indicating that banks were able to cut their labor force after the financial crisis but were less flexible to reduce physical capital input. Furthermore, significant differences in labor cost share are detected across countries, suggesting that different countries have different bank production functions. The variations in labor cost share are significantly positively related to the country's financial services wage rate, suggesting that banks using relatively more labor in a particular country is due to the labor force productivity, rather than labor being cheap.
\end{abstract}

Please send correspondence to: Simon Kwan, Research Advisor, Federal Reserve Bank of San Francisco, 101 Market Street, San Francisco, CA 94105, U.S.A.

Telephone: 415-974-3485; Fax: 415-974-2168; E-mail: simon.kwan@sf.frb.org

The findings, interpretations, and views expressed in this paper are those of the author only and do not necessarily represent the views of the Federal Reserve Bank of San Francisco or the Federal Reserve System. Thanks are due to the anonymous referee, participants at the Federal Reserve System Conference on International Economic Analysis and the 2001 Australasian Finance and Banking Conference for helpful comments. Irene Wang provided excellent research assistance. 


\section{Operating Performance of Banks Among Asian Economies: An International and Time Series Comparison}

\section{Introduction}

In banking research, there is a large body of literature studying the efficiency of financial institutions, including both scale and scope economies and an increasing focus on X-efficiency. These studies strongly suggest that X-efficiency in banking is large, typically accounting for twenty percent or more of costs, and dominate scale and scope efficiencies [Berger and Humphrey (1997)]. While banking efficiency research has been conducted quite extensively for U.S. commercial banks, and to a lesser extent, for European financial institutions, relatively little research has been done to investigate banking production among Asian financial institutions. Furthermore, from an international perspective, there is very little research on comparing banking production across Asian countries.

A number of Asian economies, such as Hong Kong, Singapore, and South Korea, are considered highly competitive and demonstrate somewhat different productivity dynamics, including the substitution between labor and capital, than western economies. At the same time, there are considerable variations in the structure of the financial services industry, the scope of banking supervision and regulation, the development of local financial markets, and the openness of the banking industry to foreign competition across these Asian countries. ${ }^{1}$ Moreover, the coincidence of banking and currency problems associated with recent Asian

${ }^{1}$ See for example, Beck, Demirguc-Kunt, and Levine (1999) and Demirguc-Kunt and Levine (1999) for cross-country comparisons of financial developments, Barth, Caprio, and Levine (2001) for the regulation and supervision of banks around the world and cross-country comparisons of the structure of the financial services industry, Claessens and Glaessner (1998) and Barth, Caprio, and Levine (2001) for the openness of the banking sector to foreign competition. 
financial crises has drawn renewed attention to the development of the banking sector among Asian economies [Glick and Hutchison (2000)].

To shed light on the micro production of banking outputs in Asia, this paper empirically examines the banking industry's per unit operating costs in seven Asian economies, including Hong Kong, Indonesia, Malaysia, Philippines, Singapore, South Korea and Thailand, from 1992 to 1999 . First, the cross-country comparison provides insights into the relative efficiency of the banking industry among these Asian economies. Second, the time series analysis reveals how banking production, and in particular the choice between labor and physical capital, evolve over time; it also captures the effect of the Asian financial crisis on banking production.

The rest of this paper is organized as follows. Section 2 briefly discusses existing banking literature that is related to this study. Section 3 describes the data used in the analysis. The empirical analysis and findings are presented in Section 4. Section 5 summarizes and concludes this study.

\section{Literature Review}

The efficiency of the financial services industry has long been a focus of banking research. The amount of attention that banking efficiency research has received is understandable. Their findings have obvious implications for bank management who seek to improve operating performance, and for policy makers who concern about banking competition and bank safety and soundness. Research that shows a positive relation between finance and growth [see for example, Levine (1999), Levine and Zervos (1998), and Beck, Levine and Loayza (2000)] prompts additional studies to focus more narrowly on the banking system 
[Demirguc-Kunt and Levine (1999) and Levine, Loayza, and Beck (2000)]. A natural extension of this line of inquiry is to compare the efficiency of the banking system across countries.

Berger and Humphrey (1997) survey over 100 studies that apply frontier efficiency analysis to financial institutions in 21 countries. In studying cross-border banking performance, Berger, DeYoung, Genay, and Udell (1999) review the literature that provide international comparison of banking efficiency. In short, studies of the efficiency of Asian financial institutions are relatively few, compared to research on U.S. and European banking. Altunbas, Liu, Molyneux and Seth (2000) study the efficiency and risk in Japanese banking. Okuda (2000) estimates the cost function of Philippines domestic banks for the pre-Asian crisis period. Leightner (1999) uses linear programming techniques to evaluate the performance of Thailand's finance and securities companies over the 1990-1995 period. Huang, Fu, and Huang (1999) examine the efficiency of Taiwan's farmers' credit union.

One obstacle in researching the efficiency of Asian banks is the lack of publicly available data for non-publicly traded Asian financial institutions. Together with the fact that in certain Asian countries, a few large banks dominate the banking industry, researchers may find too few observations to estimate the efficient frontier in a given country. Furthermore, X-efficiency is a relative concept which involves comparing banks to the best practice institutions. The comparison is meaningful only when all the sample banks have equal access to the same production technology. This assumption is unlikely to hold in a cross country setting. Thus, in this paper, rather than estimating a global efficient frontier, we rely on accounting measures to compare operating efficiency across countries after controlling for bank characteristics and output mix. Although using accounting variables is arguably less preferable to using the frontier 
method to measure efficiency when data availability is not an issue, our results appear to be fairly strong and robust.

Claessens and Glaessner (1998) also compare bank performance across several Asian countries in their study of the internationalization of financial services. However, their focus is more on the profit side rather than the operating side of financial institutions. One similarity between their study and this paper is that we also try to link operating efficiency to the openness of the financial sector. This is motivated by the work of Levine (1996), Walter and Gray (1983), Gelb and Sagari (1990), and Classens, Demirguc-Kunt, and Huizinga (1998) which found that foreign bank entry seems to have a positive effect on domestic banking markets. Finally, Barth, Caprio, and Levine (2000) study banking systems around the world, focusing on the question of whether regulation and ownership affect performance and stability.

\section{Data Description}

The data for this study comprise the population of commercial banks in Hong Kong, Indonesia, Malaysia, Philippines, Singapore, South Korea and Thailand that are listed in the IBCA bank credit rating agencies Bankscope database, which reports published financial statements from financial institutions worldwide. ${ }^{2}$ To focus on commercial banks and to maintain consistency across countries, only commercial banks that make commercial loans and accept deposits from public are included in the analysis. Therefore, deposit taking companies,

${ }^{2}$ Bankscope does not cover foreign branches and agencies that are wholly owned by foreign banks. Hence, most of the sample banks are locally owned. Nevertheless, it is still possible for foreigners to own stocks of a local bank, making the ownership status somewhat ambiguous. Unfortunately, data on ownership status are not readily available. 
trust banks, finance companies, private banks, and savings institutions are excluded. Appendix 1 shows the ratio of total assets of the final bank sample to the total assets of all financial institutions covered by Bankscope as of 1999 by country. In the cases of Hong Kong, Malaysia, Philippines, Singapore, and Thailand, the final sample represents over $95 \%$ of all publicly held financial institutions in these countries. The final sample represents $77 \%$ of Indonesian financial institution assets and $60 \%$ of Korean financial institution assets.

Since Bankscope reports individual banks' historical financial statements usually back to 1992, and a large number of banks have not yet released their 2000 financial statements, the study period is from 1992 to $1999 .^{3}$ During the study period, banks that were acquired or failed are dropped from the Bankscope database so that the final sample contains only surviving banks as of 2000. It should be noted that all countries being analyzed are subject to the same survival bias, so that the comparisons across countries would still be valid.

The annual balance sheet and income statement are used to construct the variables for the empirical analysis. To the extent that the cost variables used in the analysis are expressed as a ratio to total assets, it is not necessary to convert the financial statement variables into a common currency for international comparison. (For descriptive statistics, we convert total assets into U.S. dollars.) Table 1 provides sample statistics by country for 1999.

Panel A of Table 1 shows that on average, banks in Korea are the largest among the seven countries, although the largest bank is located in Hong Kong. The average bank in Hong Kong, Singapore, and Thailand are of similar size, while Indonesia, Malaysia, and Philippines

3 Data for banks in Hong Kong are unavailable for 1992, and for banks in Singapore are unavailable from 1992 to 1995. 
tend to have smaller banks. Indonesia has the largest number of banks in the sample, while Singapore has the fewest. Panel B shows that both Indonesia and Philippines have respectively the highest mean and median total operating costs per dollar asset, while Singapore has the lowest observed operating costs. Panel C and Panel D show broadly similar pattern for the distributions of the two components of operating costs: labor cost and capital cost for the Asian countries. Panel E shows the ratio of loans (net of provisions for losses) to total assets across countries. The average bank in Thailand has the highest loan to asset ratio, while the average bank in Indonesia has the lowest ratio. The average loan ratio for the other five countries clusters around 50 to 60 percent. Despite the potential difference in banking powers across countries [Barth, Caprio, and Levine (2001)], the average loan-to-asset ratio does not seem to vary that much across countries.

Two pieces of country specific data are also collected. First, the average wage rate in the financial services industry by country is collected from the International Labor Organization's Laborsta database. The annual wage data is available for Hong Kong, Singapore, South Korea, and Thailand for the entire sampling period. It is available only through 1995 for Philippines. For Malaysia, the wage data is available for only a few industries. No wage data is available for Indonesia. Thus, Indonesia will be dropped from the analysis that uses wage data. We extrapolate the Philippines wage data to 1999 using the historical growth rate, and estimate Malaysia's wage rate in the financial services industry using the sectoral wage distribution relationship in Singapore and Thailand, the two economies that seem to be closest to Malaysia by proximity and overall economic structure. Table 2 provides the average wage rate converted into U.S. dollar using prevailing exchange rate for the financial services industry in the six Asian 
economies from 1992 to $1999 .{ }^{4}$ Hong Kong, Korea, and Singapore's average wage rates in the financial services industry are in the order of two to three times higher than those in Malaysia and Thailand, whose average wage rates in turn are almost twice as high as that in Philippines. Between 1992 and 1999, Singapore experienced the fastest growth in finance wages, at a compound annual rate of $9.87 \%$, while the other Asian countries's finance wages were growing at around $4 \%$ with the exception of Philippines whose wage rate were growing at only $1.5 \%$.

Second, to measure the degree of openness of the banking sector to foreign competition, we use the banking openness index by Claessens and Glaessner (1998), as shown in Table 3. The index summarizes the degree of entry barriers as of the end of 1996 on a scale of 1 (being most closed) to 5 (being most open). Their indicator weighs the various type of barriers, including the right of establishment and ownership, limits on business activity (such as the ability to establish branch offices and ATMs, restrictions on lending, deposit taking, or other banking activities), and residency requirements. The Claessens and Glaessner bank openness index further distinguishes between country commitment and existing practice. The commitment index reflects individual countries commitment to financial services liberalization under the Financial Services Agreement of the 1995 General Agreement on Trade and Services (GATS). As of 1996, Hong Kong has the highest commitment to an open banking sector, followed by Indonesia, Thailand, Philippines, Malaysia, Singapore, and South Korea. The

${ }^{4}$ For international comparison, it may be more preferable to convert the local currency wage rate into an international currency using the PPP rate. Unfortunately, the Penn World Table by Summers and Heston (1991) has the PPP rate only up to 1992. Although using the market rate to convert the wage rate into U.S. dollar may be slightly less preferable, the measurement error is likely to be relatively small given the large variation in wage rate across countries. 
practice index reflects the then current practices on financial liberalization. Philippines is relatively more open under the practice index than under the commitment index, while the other six countries exhibit similar ratings under either index.

\section{Empirical Analysis}

\section{A. Cost Efficiency}

The first set of issues is to compare the banking production costs across the seven Asian economies. In this paper, we focus on the operating costs of producing banking products and abstract from the funding cost component, which is driven predominately by domestic interest rates. Total operating cost is further broken down into labor cost and cost of physical capital. To create per unit cost measure, we deflate the operating cost and its two components by either (i) the total earning assets, which is justified by the asset approach in measuring banking outputs, or (ii) the sum of total earning assets and total deposits, which can be justified by the intermediation approach in measuring banking outputs.

To examine whether production costs vary systematically across countries and over time, the following fixed-effect regression model is estimated:

$$
\mathrm{C}_{\mathrm{jt}}=\alpha+\beta \mathrm{X}_{\mathrm{jt}}+\gamma \mathrm{D}_{\mathrm{j}}+\delta \mathrm{T}_{\mathrm{t}}+\varepsilon_{\mathrm{jt}}
$$

where

$\mathrm{C}_{\mathrm{jt}}=$ observed cost for the jth bank at year $\mathrm{t}$;

$\mathrm{X}_{\mathrm{jt}}=$ vector of control variables;

$D_{j}=$ vector of country specific dummy variables; 
$T_{t}=$ vector of time specific dummy variables;

$\alpha, \beta, \gamma$, and $\delta$ are vectors of regression coefficients; and

$\epsilon_{\mathrm{jt}}$ is the disturbance term.

The dependent variable $\mathrm{C}$ consists one of the following three cost measures: total operating costs, labor cost, and physical capital cost. Five control variables are included in the $\mathrm{X}$ vector: the ratio of loan loss provision to total loans, the ratio of cash and due from banks to total assets, the ratio of equity capital to total assets, the ratio of retail deposits to total deposits, and the ratio of total loans to total earning assets. The ratio of loan loss provision to total loans is used to proxy for output quality. ${ }^{5}$ If banks which spend more resources on credit underwriting and loan monitoring would have less problem loans at the expense of higher operating costs, the coefficient of the loan loss provisioning ratio would be negative [Mester (1996)]. On the other hand, if loan quality is endogenous in the quality of management, an inefficient bank with high operating costs would also have more problem loans, so that loan loss provisioning would be positively related to operating costs [Berger and DeYoung (1997)]. The ratio of cash and due from banks to total assets control for the liquidity of the bank. While liquid assets reduce the bank's liquidity risk, they may be more costly to handle as these assets may involve additional transportation cost, storage and protection costs, and labor cost. Thus, the cash ratio is expected to have a positive coefficient. The ratio of equity capital to total assets further captures the quality of bank management and risk preference. To the extent that well capitalized banks

${ }^{5}$ Problem loans were reported for less than half of the sample banks. Therefore, we use loan loss provision rather than problem loans to proxy for loan quality. 
reflect both high quality management and aversion to risk taking, these banks are likely to be more cost efficient in producing banking outputs. Thus, the equity ratio is expected to have a negative coefficient. Finally, the ratio of retail deposits to total deposits and the ratio of loans to total assets are included to control for output mix. Since retail deposits are more costly to service than wholesale deposits, the coefficient of the ratio of retail deposits to total deposits is expected to be positive. Similarly, since loans are more costly to produce than investment securities, the ratio of loans to total earning assets is expected to have a positive coefficient. Note that both the deposit ratio and the loan ratio also control for the potential variation in banking powers across countries.

After controlling for managerial quality, risk preference, liquidity, and output mix, the country specific dummy variables test whether there are systematic differences in operating costs across countries. Country specific factors including the productivity of the labor force and the efficiency in resource utilization will be summed up by the coefficient of the country dummies. For identification purpose, the dummy variable for Hong Kong is excluded so that the estimated coefficients measure the production efficiency of the six Asian countries relative to Hong Kong.

The time-specific dummy variables test whether there are systematic changes in production costs over time. Technological innovations including the increasing adoption of information processing equipment in banking may lead to lower production costs. Exogenous shock such as the Asian financial crisis may boost operating costs as additional resources may be needed to deal with the piling up of problem loans. Again, for identification purpose, the dummy for 1992 is excluded so that the time dummies measure the time effect relative to 1992.

Table 4 presents the regression estimates of equation (1) with total operating costs as the 
dependent variable. The t-statistics are calculated using the White (1980) heteroskedasticityconsistent standard errors. In the first column, total operating costs are deflated by total earning assets; in the second column, total operating costs are deflated by total earning assets plus total deposits. Both versions of the model fit the data reasonably well and yield very similar results. The adjusted R-square is about 45 percent. The coefficient of the cash-to-asset ratio is significantly positive, confirming that liquid assets tend to raise operating costs. The two variables controlling for output mix are both significantly positive. The findings indicate that retail deposits are more costly to service than wholesale deposits, and loans are more costly to produce than other earning assets. Interestingly, both the loan loss provision variable and the equity-to-asset ratio are insignificant. The results suggest that banking production costs are not related to loan quality nor capitalization of the bank, both of which capturing managerial quality.

Regarding the country effect dummies, all but Singapore have significantly positive coefficients. The findings indicate that on average, the unit cost of production between banks in Hong Kong and banks in Singapore is indistinguishable. The per unit production cost in the remaining five Asian countries on average is significantly higher than in Hong Kong. Based on the coefficient estimates of the country dummies, on average, Philippines has the highest observed operating costs, followed by South Korea, Indonesia, Thailand, and Malaysia.

All of the time effect dummies have significantly negative coefficients. Their coefficient estimates indicate that on average per unit production cost among the seven Asian countries were declining from 1992 to 1996, but turned back up from 1997 to 1999. Before 1997, the declining production cost in these Asian countries suggests that banks were improving their operating performance. The run-up in per unit operating costs since 1997 coincides with the 
Asian financial crisis, which is consistent with requiring additional resources to deal with problem loans while output was declining.

To delve deeper into the production process, Table 5 and Table 6 present the regression estimates of equation (1) with labor cost and physical capital cost as the dependent variable, respectively. Table 5 shows that the labor cost regression gives broadly similar results as the total cost regression. Per unit labor cost is found to be positively related to liquidity, and is statistically significant when outputs are measured by earnings assets. In both versions of the model, labor cost is found to be significantly positively related to retail deposits and loan production. All of the six country effect dummies are significant. On average, per unit labor cost is found to be highest in Philippines, followed by South Korea, Indonesia, Malaysia, Hong Kong, Thailand, and Singapore. While Hong Kong has lower per unit total cost than Thailand, Thailand has lower per unit labor cost than Hong Kong. Coefficients of the time effect dummies reveal that per unit labor cost were declining from 1992 to 1997 and then stayed flat until 1999, providing evidence that labor productivity in banking were improving among these Asian countries between 1992 and 1997. Between 1997 and 1999, banking outputs were falling as a result of the Asian financial crisis. The finding of a fairly constant per unit labor cost during the last several years of the study period indicates that banks were adjusting their labor input to declining outputs.

Table 6 shows that per unit cost of physical capital is positively related to liquidity, but again unrelated to loan quality nor capitalization. It is positively related to the ratio of retail deposits to total deposits, indicating that producing retail deposits significantly raises physical cost of capital, perhaps stemming from the operation of branches and ATMs. However, physical 
cost of capital is found to be unrelated to the ratio of loans to earning assets. Thus, while loan production is labor intensive, it does not seem to require more capital to produce than other earning assets. Estimates for the country effect dummies are similar to the total cost regression and have exactly the same country ranking. Regarding the time effect dummies, while the coefficients for 1993 to 1997 are significantly negative, it is insignificant in 1998 and 1999. Thus, whatever improvement in the utilization of physical resources before 1997 was dissipated by 1999 . This may be due to the fact that banks were less flexible to adjust their physical capital input than labor input upon falling demand after the Asian financial crisis.

It is somewhat interesting to note that the country ranking in per unit labor cost is similar to the ranking in per unit physical capital cost. While Philippines, South Korea, and Indonesia exhibit the three highest per unit labor cost among the seven Asian economies, they also have the three highest per unit physical capital cost. Singapore has both the lowest per unit labor cost and the lowest physical capital cost. Thus, labor productivity is strongly correlated with the efficiency in physical resource utilization. Indeed, regressing the country dummies from the labor cost model (with the inclusion of the Hong Kong dummy by suppressing the intercept term) on the country dummies from the physical capital cost model gives an adjusted R-square of $73 \%$ (not shown). Hence, it seems reasonable that the country specific dummy variables from the total operating cost regressions capture the operating efficiency of the banking industry in that country.

While there are many factors underlying the cross country variations in operating efficiency, researchers and policy makers argue that the degree of openness of the banking sector to foreign competition may have something to do with efficiency. To examine whether the 
country specific effect on operating efficiency is related to the openness of the banking sector, the coefficients of the country effect dummies (including Hong Kong) from the total operating cost model is regressed on the Claessens and Glaessner (1998) banking sector openness index. The regression results (not shown) indicate that country specific operating efficiency is unrelated to openness. Figures 1 and 2 plot the country specific operating efficiency against the openness index, expressed in both commitment and practice. There do not seem to be any discernable patterns on the relationship between efficiency and openness.

\section{B. Choice of Inputs}

The second set of issues to examine is the choice of input mix, i.e., the mix of labor and physical capital, in bank production across the seven Asian economies. To examine whether input mix vary systematically across countries and over time, the following regression model is estimated:

$$
\mathrm{M}_{\mathrm{jt}}=\alpha+\beta \mathrm{X}_{\mathrm{jt}}+\gamma \mathrm{D}_{\mathrm{j}}+\delta \mathrm{T}_{\mathrm{t}}+\varepsilon_{\mathrm{jt}}
$$

where

$\mathrm{M}_{\mathrm{jt}}=$ the ratio of labor cost to total operating costs for the jth bank at year $\mathrm{t}$;

$\mathrm{X}_{\mathrm{jt}}=$ vector of control variables;

$D_{j}=$ vector of country specific dummy variables;

$T_{t}=$ vector of time specific dummy variables;

$\alpha, \beta, \gamma$, and $\delta$ are vectors of regression coefficients; and

$\epsilon_{\mathrm{jt}}$ is the disturbance term.

In equation (2), the ratio of labor cost to total operating costs is the dependent variable. 
The same set of variables used as control variables in equation (1) is included: the ratio of loan loss provision to total loans, the ratio of cash and due from banks to total assets, the ratio of equity capital to total assets, the ratio of retail deposits to total deposits, and the ratio of total loans to total earning assets. Since banking theory is silence on the substitution between labor and capital in the production process, these variables test whether the share of labor cost vary with loan quality, financial capital, liquidity, and output mix.

The country specific dummy variables test whether there are systematic differences in the substitution between labor and physical capital across countries. This can be due to variations in wage rate and technology adoption across countries. For identification purpose, the dummy for Hong Kong is excluded so that the coefficient of the country dummy measures the difference in labor share relative to Hong Kong.

The time specific dummies test for systematic time effects on labor share. This can be due to advances in technology that replace labor by machines. For example, advances in credit scoring could replace loan officers by computers, and the adoption of ATM machines could replace bank tellers. The dummy for 1992 is excluded for identification.

Table 7 reports the regression estimates of equation (2) with the t-statistics computed from heteroskedasticity-consistent standard errors. The labor cost share is significantly negatively related to loan loss provisioning but unrelated to the ratio of loan to earning assets. While labor and capital seem to be good substitute for each other in loan production, banks with higher loan losses tend to use relatively less labor in their production. Thus, although both human and machines seem to be doing equally well in churning out a given amount of loans, the association between loan quality and labor cost share suggests that credit underwriting and loan 
monitoring perhaps are more effectively done by human than by machines. The labor cost share is also found to be significantly positively related to the ratio of retail to total deposits, suggesting that the production of retail deposits is relatively more labor intensive than capital intensive. The labor cost share is found to be unrelated to liquidity nor capitalization.

All six country specific dummy variables are significantly negative, indicating that they all exhibit significantly different cost share than Hong Kong. On average, banks in Thailand has the lowest labor cost share in their production process, followed by Philippines, South Korea, Indonesia, Singapore, Malaysia, and Hong Kong. The findings indicate that banks in different countries employ different production functions to generate banking outputs. Furthermore, the labor cost share is found to decline significantly between 1997 and 1999, possibly due to the fact that banks laid off workers in response to falling outputs following the Asian financial crisis but less flexible to adjust their physical capital inputs.

Banks in one country tend to use relatively more labor than capital in their production process than another country possibly because either that labor is relatively cheap compared to capital investment, or that the labor productivity is relatively high. To distinguish between the two hypotheses, the following model adapted from equation (2) is estimated:

$$
\mathrm{M}_{\mathrm{jt}}=\alpha+\beta \mathrm{X}_{\mathrm{jt}}+\gamma \mathrm{W}_{\mathrm{jt}}+\varepsilon_{\mathrm{jt}}
$$

where

$\mathrm{M}_{\mathrm{jt}}=$ the ratio of labor cost to total operating costs for the jth bank at year $\mathrm{t}$;

$\mathrm{X}_{\mathrm{jt}}=$ vector of control variables;

$\mathrm{w}_{\mathrm{jt}}=$ wage rate for jth bank's country at year $\mathrm{t}$;

$\alpha, \beta$, and $\gamma$ are vectors of regression coefficients; and 
$\epsilon_{\mathrm{jt}}$ is the disturbance term.

The wage rate in equation (3) is the reported or estimated wage rate for the financial services industry denominated in U.S. dollar for each of the six countries shown in Table 2. A negative coefficient of $\gamma$ would be consistent with the hypothesis that banks use relatively more labor in a particular country because labor is cheaper in that country. Alternatively, to the extent that a productive labor force should command a higher wage rate, ceteris paribus, a positive coefficient of $\gamma$ would be consistent with the hypothesis that banks use more labor in their production process because they are more productive.

Results of estimating equation (3) by OLS are presented in Table $8 .{ }^{6}$ Estimates of the control variables are broadly consistent with those reported in Table 7. In addition, the liquidity ratio, capitalization ratio, and the ratio of loans to earning assets become statistically significant. The coefficient of the wage variable is positive and highly statistically significant. The findings provide support to the hypothesis that banks use more labor in a given country because they are more productive, not because they are cheaper.

\section{Summary and Conclusions}

This paper compares the observed bank operating costs across seven Asian economies. After controlling for loan quality, liquidity, capitalization, and output mix, per unit operating costs are found to vary significantly across countries and over time. Further analysis of the two components of operating costs - the labor cost and the cost of physical capital - reveals that the country ranking of per unit labor cost and the country ranking of per unit physical capital cost

\footnotetext{
${ }^{6}$ Including time effect dummies in equation (3) produces qualitatively similar results.
} 
are highly correlated, suggesting that countries with high labor cost in their banking operation also incur high capital cost. Thus, using per unit operating cost as a measure of efficiency, the results suggest that there exist systematic differences in bank operating efficiency across these Asian countries. However, this measure of operating efficiency is found to be unrelated to the degree of openness of the banking sector.

In addition, we find that bank operating costs among these Asian countries were declining from 1992 to 1997, indicating that banks on average were improving their operating performance over time. Since 1997, the run-up in per unit operating costs coincided with the Asian financial crisis, suggesting that banks were incurring additional costs in dealing with their problem loans while output was declining simultaneously. Moreover, the labor cost share is found to decline significantly between 1997 and 1999, suggesting that banks were adjusting their labor input upon falling demand but less flexible in reducing physical capital input.

With respect to the choice of input mix in bank production, significant differences in labor cost share are detected across countries, suggesting that different countries have different bank production functions. More importantly, we found that the variations in labor cost share across countries are significantly positively related to the country's financial services wage rate, providing evidence that banks use relatively more labor in a given country is because their country's banking labor force is more productive, not because they are cheaper. 


\section{References}

Altunbas, Y., M.H. Liu, P. Molyneux, and R. Seth, 2000, Efficiency and risk in Japanese banking, Journal of Banking and Finance 24, 1605-1628.

Barth, J.R., G. Caprio, and R. Levine, 2000, Banking systems around the world: Do regulation and ownership affect performance and stability? in Federic Mishkin, ed.: Prudential Supervision: What Works and What Doesn't, (NBER Press, Cambridge, MA).

Barth, J.R., G. Caprio, and R. Levine, 2001, The regulation and supervision of banks around the world - A new database, Working paper, World Bank.

Beck, T., A. Demirguc-Kunt, and R. Levine, 1999, A new database on financial development and structure, Working paper, World Bank

Beck, T., R. Levine, and N. Loayza, 2000, Finance and the sources of growth, Journal of Financial Economics 58, 261-300.

Berger, A.N., and R. DeYoung, 1997, Problem loans and cost efficiency in commercial banks, Journal of Banking and Finance 21, 849-870.

Berger, A.N., R. DeYoung, H. Genay, and G.F. Udell, 1999, Globalization of financial institutions: Evidence from cross-border banking performance, Working paper, Federal Reserve Bank of Chicago

Berger, A.N., and D.B. Humphrey, 1997, Efficiency of financial institutions: International survey and directions for future research, Working paper, Board of Governors of the Federal Reserve System

Classens, S., and T. Glaessner, 1998, Internationalization of financial services in Asia, Working paper, World Bank.

Classens, S., A. Demirguc-Kunt, and H. Huizinga, 1998, How does foreign entry affect the domestic banking market? Working paper, World Bank.

Demirguc-Kunt, A., and R. Levine, 1999, Bank-based and market-based financial systems: Cross-country comparisons, Working paper, World Bank.

Gelb, A., and S. Sagari, 1990, Banking, in P. Messerlin and K. Sanvant, eds., The Uruguay Round: Services in the World Economy, Washington, D.C.: The World Bank and UN Center on Transnational Corporations.

Glick, R., and M. Hutchison, 2000, Banking and currency crisis: How common are the twins? Forthcoming in Financial Crises in Emerging Markets, ed. Reuven Glick, Ramon Moreno, and 
Mark Spiegel. NY: Cambridge University Press.

Huang, C.J., T.T. Fu, and M.Y. Huang, 1999, Cost efficiency of the farmers' credit unions in Taiwan, in Tsu-Tan Fu, Cliff J. Huang, and C.A. Knox Lovell, ed.: Economic Efficiency and Productivity Growth in the Asia-Pacific Region, (Edward Elgar Publishing, Northampton, MA).

Leightner, J.E., 1999, The Achilles' heel of Thailand's financial market, in Tsu-Tan Fu, Cliff J. Huang, and C.A. Knox Lovell, ed.: Economic Efficiency and Productivity Growth in the AsiaPacific Region, (Edward Elgar Publishing, Northampton, MA).

Levine, Ross, 1996, Foreign banks, financial development, and economic growth, in Claude E. Barfied, ed., International Financial Markets, Washington, D.C., AEI Press.

Levine, R., 1999, Law, finance, and economic growth, Journal of Financial Intermediation 8, 835 .

Levine, R., N. Loayza, and T. Beck, 2000, Financial intermediation and growth: Causality and causes, Journal of Monetary Economics 46, 31-77.

Levine, R., and S. Zervos, 1998, Stock markets, banks, and economic growth, American Economic Review 88, 537-558.

Mester, L.J., 1996, A study of bank efficiency taking into account risk-preferences, Journal of Banking and Finance 20, 1024-1045.

Okuda, H., 2000, The production technology of Philippine domestic banks in the pre-Asian Crisis Period: Estimation of the cost functions in the 1990-96 period, Working paper, Hitotsubashi University.

Summers, R., and A. Heston, 1991, The Penn World Table (Mark 5): An expanded set of international comparisons, 1950-1988, The Quaterly Journal of Economics, 327-368.

Walter, I., and H. P. Gray, 1983, Protectionism, and international banking, sectoral efficiency, competitive structure and national policy, Journal of Banking and Finance 7, 597-609.

White, H., 1980, A heteroskedasticity-consistent covariance matrix estimator and a direct test for heteroskedasticity, Econometrica 48, 817-838. 


\section{Appendix 1}

Ratio of total bank assets in the final sample to total financial institution assets covered by Bankscope as of 1999.

\begin{tabular}{|l|c|}
\hline Country & Sample Representation Ratio \\
\hline Hong Kong & $98 \%$ \\
\hline Indonesia & $77 \%$ \\
\hline Korea & $60 \%$ \\
\hline Malaysia & $99 \%$ \\
\hline Philippines & $100 \%$ \\
\hline Singapore & $96 \%$ \\
\hline Thailand & $96 \%$ \\
\hline
\end{tabular}


Table 1: Descriptive statistics for 1999

Panel A: Total Assets (\$Billion)

\begin{tabular}{|l|c|c|c|c|c|}
\hline Country & Mean & Median & Minimum & Maximum & $\mathrm{N}$ \\
\hline Hong Kong & 16.5 & 4.9 & 0.3 & 211.1 & 24 \\
\hline Indonesia & 1.5 & 0.2 & 0.03 & 31.9 & 50 \\
\hline Korea & 30.7 & 32.1 & 6.2 & 63.7 & 9 \\
\hline Malaysia & 4.1 & 2.2 & 0.1 & 30.9 & 34 \\
\hline Philippines & 2.1 & 1.2 & 0.1 & 10.0 & 29 \\
\hline Singapore & 15.6 & 14.5 & 0.4 & 33.9 & 7 \\
\hline Thailand & 12.6 & 8.7 & 1.7 & 31.6 & 11 \\
\hline
\end{tabular}

Panel B: Ratio of Total Operating Costs to Total Assets

\begin{tabular}{|l|c|c|c|c|c|}
\hline Country & Mean & Median & Minimum & Maximum & $\mathrm{N}$ \\
\hline Hong Kong & $1.20 \%$ & $1.14 \%$ & $0.67 \%$ & $2.17 \%$ & 24 \\
\hline Indonesia & $3.76 \%$ & $2.92 \%$ & $0.95 \%$ & $16.67 \%$ & 50 \\
\hline Korea & $1.82 \%$ & $1.87 \%$ & $1.26 \%$ & $2.44 \%$ & 9 \\
\hline Malaysia & $1.61 \%$ & $1.55 \%$ & $0.57 \%$ & $2.86 \%$ & 34 \\
\hline Philippines & $3.65 \%$ & $3.46 \%$ & $2.37 \%$ & $6.43 \%$ & 29 \\
\hline Singapore & $0.91 \%$ & $0.97 \%$ & $0.21 \%$ & $1.31 \%$ & 7 \\
\hline Thailand & $2.72 \%$ & $2.40 \%$ & $1.25 \%$ & $4.86 \%$ & 11 \\
\hline
\end{tabular}


Panel C: Ratio of Total Labor Cost to Total Assets

\begin{tabular}{|l|c|c|c|c|c|}
\hline Country & Mean & Median & Minimum & Maximum & $\mathrm{N}$ \\
\hline Hong Kong & $0.69 \%$ & $0.63 \%$ & $0.44 \%$ & $1.05 \%$ & 24 \\
\hline Indonesia & $1.31 \%$ & $1.06 \%$ & $0.24 \%$ & $5.70 \%$ & 50 \\
\hline Korea & $0.87 \%$ & $0.79 \%$ & $0.51 \%$ & $1.70 \%$ & 9 \\
\hline Malaysia & $0.81 \%$ & $0.78 \%$ & $0.28 \%$ & $1.78 \%$ & 34 \\
\hline Philippines & $1.35 \%$ & $1.29 \%$ & $0.76 \%$ & $2.56 \%$ & 29 \\
\hline Singapore & $0.38 \%$ & $0.42 \%$ & $0.11 \%$ & $0.58 \%$ & 7 \\
\hline Thailand & $0.78 \%$ & $0.77 \%$ & $0.17 \%$ & 1.61 & 11 \\
\hline
\end{tabular}

Panel D: Ratio of Physical Capital Cost to Total Assets

\begin{tabular}{|l|c|c|c|c|c|}
\hline Country & Mean & Median & Minimum & Maximum & $\mathrm{N}$ \\
\hline Hong Kong & $0.52 \%$ & $0.48 \%$ & $0.22 \%$ & $1.12 \%$ & 24 \\
\hline Indonesia & $2.45 \%$ & $1.63 \%$ & $0.09 \%$ & $15.85 \%$ & 50 \\
\hline Korea & $0.95 \%$ & $0.87 \%$ & $0.74 \%$ & $1.75 \%$ & 9 \\
\hline Malaysia & $0.80 \%$ & $0.77 \%$ & $0.28 \%$ & $1.60 \%$ & 34 \\
\hline Philippines & $2.30 \%$ & $2.23 \%$ & $1.44 \%$ & $4.15 \%$ & 29 \\
\hline Singapore & $0.53 \%$ & $0.52 \%$ & $0.10 \%$ & $1.10 \%$ & 7 \\
\hline Thailand & $1.95 \%$ & $1.66 \%$ & $1.08 \%$ & $3.84 \%$ & 11 \\
\hline
\end{tabular}

Panel E: Ratio of Loans (Net of Provision for Losses) to Total Assets

\begin{tabular}{|l|c|c|c|c|c|}
\hline Country & Mean & Median & Minimum & Maximum & $\mathrm{N}$ \\
\hline Hong Kong & $52.37 \%$ & $52.76 \%$ & $33.26 \%$ & $67.83 \%$ & 24 \\
\hline Indonesia & $39.96 \%$ & $32.52 \%$ & $7.63 \%$ & $87.88 \%$ & 50 \\
\hline Korea & $52.15 \%$ & $50.66 \%$ & $43.16 \%$ & $63.94 \%$ & 9 \\
\hline Malaysia & $58.43 \%$ & $63.42 \%$ & $13.77 \%$ & $85.68 \%$ & 34 \\
\hline Philippines & $57.38 \%$ & $59.67 \%$ & $44.89 \%$ & $71.67 \%$ & 29 \\
\hline Singapore & $63.10 \%$ & $60.93 \%$ & $48.25 \%$ & $85.08 \%$ & 7 \\
\hline Thailand & $73.25 \%$ & $73.64 \%$ & $64.49 \%$ & $85.76 \%$ & 11 \\
\hline
\end{tabular}


Table 2: Average wage rate per month in the financial services industry (in \$U.S.)

\begin{tabular}{|l|c|c|c|c|c|c|c|c|}
\hline & 1992 & 1993 & 1994 & 1995 & 1996 & 1997 & 1998 & 1999 \\
\hline Hong Kong & 1171.10 & 1119.60 & 1176.73 & 1330.41 & 1338.36 & 1413.86 & 1451.94 & 1507.40 \\
\hline Korea & 1342.99 & 1759.20 & 1943.78 & 2365.24 & 2467.70 & 2167.68 & 1404.27 & 1862.35 \\
\hline Malaysia $^{1}$ & 517.29 & 575.45 & 578.34 & 635.62 & 685.25 & 634.07 & 567.86 & 668.20 \\
\hline Philippines $^{2}$ & 298.65 & 303.80 & 356.54 & 358.17 & 390.27 & 280.44 & 313.62 & 332.04 \\
\hline Singapore & 1378.04 & 1465.56 & 1655.42 & 1895.00 & 2005.96 & 2016.31 & 2634.13 & 2663.53 \\
\hline Thailand & 517.29 & 575.45 & 578.34 & 635.62 & 685.25 & 634.07 & 567.86 & 668.20 \\
\hline
\end{tabular}

Source: International Labor Organization

${ }^{1}$ Malaysia's wage rate in the financial services industry is estimated using Malaysia's reported wage rate for the manufacturing sector and then scaled by the sectoral wage distribution relationship in Singapore and Thailand.

${ }^{2}$ The wage rates in Philippines from 1996 to 1999 are extrapolated from historical growth rate. 
Table 3: Degree of openness index for the banking industry as of the end of 1996 (1 most closed, 5 most open)

\begin{tabular}{|l|c|c|}
\hline & Commitment & Practice \\
\hline Hong Kong & 4.20 & 4.75 \\
\hline Indonesia & 3.15 & 3.20 \\
\hline South Korea & 1.10 & 1.70 \\
\hline Malaysia & 2.40 & 2.40 \\
\hline Philippines & 2.80 & 3.35 \\
\hline Singapore & 2.25 & 2.50 \\
\hline Thailand & 2.95 & 2.85 \\
\hline
\end{tabular}

Source: Classens and Glaessner (1998) 


\section{Table 4: Regression Estimates of Total Operating Costs}

\begin{tabular}{|c|c|c|}
\hline & $\begin{array}{l}\text { Total operating costs to } \\
\text { earning assets }\end{array}$ & $\begin{array}{l}\text { Total operating costs to } \\
\text { earning assets }+ \text { deposits }\end{array}$ \\
\hline Intercept & $-0.0031(-0.90)$ & $-0.0031(-1.66) *$ \\
\hline Loan Loss Provisions to Total Loans & $0.0188(0.78)$ & $0.0146(1.25)$ \\
\hline Cash to Total Assets & $0.0609(3.10) * * *$ & $0.0181(1.96) * *$ \\
\hline Equity to Total Assets & $-0.0043(-0.39)$ & $0.0053(1.01)$ \\
\hline Retail Deposits to Total Deposits & $0.0188(12.54) * * *$ & $0.0108(12.64) * * *$ \\
\hline Loans to Earning Assets & $0.0085(3.29) * * *$ & $0.0053(3.44) * * *$ \\
\hline Indonesia & $0.0193(12.71) * * *$ & $0.0109(12.49) * * *$ \\
\hline South Korea & $0.0224(9.10) * * *$ & $0.0133(9.93) * * *$ \\
\hline Malaysia & $0.0044(4.21) * * *$ & $0.0024(4.90) * * *$ \\
\hline Philippines & $0.0301(25.20) * * *$ & $0.0167(26.03) * * *$ \\
\hline Singapore & $-0.0010(-.089)$ & $-0.0009(-1.53)$ \\
\hline Thailand & $0.0067(3.67) * * *$ & $0.0034(3.37) * * *$ \\
\hline 1993 & $-0.0059(-3.40) * * *$ & $-0.0029(-3.25) * * *$ \\
\hline 1994 & $-0.0074(-4.31) * * *$ & $-0.0038(-4.30) * * *$ \\
\hline 1995 & $-0.0083(-4.89) * * *$ & $-0.0042(-4.61) * * *$ \\
\hline 1996 & $-0.0108(-6.21) * * *$ & $-0.0053(-5.98) * * *$ \\
\hline 1997 & $-0.0099(-5.06) * * *$ & $-0.0049(-4.86) * * *$ \\
\hline 1998 & $-0.0070(-2.15) * *$ & $-0.0033(-2.06) * *$ \\
\hline 1999 & $-0.0074(-3.06) * * *$ & $-0.0039(-2.84) * * *$ \\
\hline Adjusted R² & 0.4311 & 0.4574 \\
\hline $\mathrm{N}$ & 1174 & 1174 \\
\hline
\end{tabular}

t-statistics, in parentheses, are computed using the White (1980) heteroskedasticity-consistent standard error.

$* * *, * *, *$ indicate significance at the $1 \%, 5 \%$, and $10 \%$ levels, respectively. 
Table 5: Regression Estimates of Labor Cost

\begin{tabular}{|c|c|c|}
\hline & $\begin{array}{l}\text { Labor cost to } \\
\text { earning assets }\end{array}$ & $\begin{array}{l}\text { Labor cost to earning } \\
\text { assets }+ \text { deposits }\end{array}$ \\
\hline Intercept & $0.0013(0.99)$ & $0.0001(0.07)$ \\
\hline Loan Loss Provisions to Total Loans & $-0.0004(-0.07)$ & $0.0028(0.97)$ \\
\hline Cash to Total Assets & $0.0179(3.40) * * *$ & $0.0033(1.33)$ \\
\hline Equity to Total Assets & $-0.0015(-0.39)$ & $0.0027(1.45)$ \\
\hline Retail Deposits to Total Deposits & $0.0087(13.86) * * *$ & $0.0049(14.37) * * *$ \\
\hline Loans to Earning Assets & $0.0053(5.23) * * *$ & $0.0034(6.48) * * *$ \\
\hline Indonesia & $0.0060(12.64) * * *$ & $0.0033(14.15) * * *$ \\
\hline South Korea & $0.0070(6.96) * * *$ & $0.0042(7.81) * * *$ \\
\hline Malaysia & $0.0017(4.13) * * *$ & $0.0009(4.45) * * *$ \\
\hline Philippines & $0.0082(14.14) * * *$ & $0.0044(16.59) * * *$ \\
\hline Singapore & $-0.0022(-4.31) * *$ & $-0.0014(-5.01) * * *$ \\
\hline Thailand & $-0.0013(-2.48) * *$ & $-0.0010(-3.40) * *$ \\
\hline 1993 & $-0.0034(-3.63) * * *$ & $-0.0017(-3.48) * * *$ \\
\hline 1994 & $-0.0043(-4.76) * * *$ & $-0.0023(-4.94) * * *$ \\
\hline 1995 & $-0.0050(-5.66) * * *$ & $-0.0029(-5.68) * * *$ \\
\hline 1996 & $-0.0059(-6.50) * * *$ & $-0.0030(-6.43) * * *$ \\
\hline 1997 & $-0.0061(-6.56) * * *$ & $-0.0032(-6.73) * * *$ \\
\hline 1998 & $-0.0059(-5.64) * * *$ & $-0.0032(-6.04) * * *$ \\
\hline 1999 & $-0.0058(-5.82) * * *$ & $-0.0032(-6.38) * * *$ \\
\hline Adjusted R² & 0.3835 & 0.4434 \\
\hline $\mathrm{N}$ & 1174 & 1174 \\
\hline
\end{tabular}

t-statistics, in parentheses, are computed using the White (1980) heteroskedasticity-consistent standard error.

$* * *, * *, *$ indicate significance at the $1 \%, 5 \%$, and $10 \%$ levels, respectively. 
Table 6: Regression Estimates of Physical Cost of Capital

\begin{tabular}{|c|c|c|}
\hline & $\begin{array}{l}\text { Physical capital cost to } \\
\text { earning assets }\end{array}$ & $\begin{array}{l}\text { Physical capital cost to } \\
\text { earning assets }+ \text { deposits }\end{array}$ \\
\hline Intercept & $-0.0044(-1.62)$ & $-0.0031(-2.02) * *$ \\
\hline Loan Loss Provisions to Total Loans & $0.0193(0.95)$ & $0.0118(1.17)$ \\
\hline Cash to Total Assets & $0.0431(2.67) * * *$ & $0.0148(1.91) *$ \\
\hline Equity to Total Assets & $-0.0028(-0.33)$ & $0.0026(0.63)$ \\
\hline Retail Deposits to Total Deposits & $0.0101(8.61) * * *$ & $0.0059(8.49) * * *$ \\
\hline Loans to Earning Assets & $0.0032(1.52)$ & $0.0018(1.39)$ \\
\hline Indonesia & $0.0132(10.35) * * *$ & $0.0076(9.72) * * *$ \\
\hline South Korea & $0.0154(7.58) * * *$ & $0.0091(7.94) * * *$ \\
\hline Malaysia & $0.0028(3.58) * * *$ & $0.0017(4.24) * * *$ \\
\hline Philippines & $0.0219(25.94) * * *$ & $0.0122(26.10) * * *$ \\
\hline Singapore & $0.0012(1.29)$ & $0.0005(0.95)$ \\
\hline Thailand & $0.0081(5.22) * * *$ & $0.0043(5.07) * * *$ \\
\hline 1993 & $-0.0025(-2.34) * *$ & $-0.0012(-2.12) * *$ \\
\hline 1994 & $-0.0031(-2.81) * * *$ & $-0.0016(-2.52) * * *$ \\
\hline 1995 & $-0.0034(-2.91) * * *$ & $-0.0016(-2.41) * *$ \\
\hline 1996 & $-0.0049(-4.40) * * *$ & $-0.0023(-3.92) * * *$ \\
\hline 1997 & $-0.0038(-2.82) * * *$ & $-0.0017(-2.36) * *$ \\
\hline 1998 & $-0.0011(-0.40)$ & $-0.0002(-0.11)$ \\
\hline 1999 & $-0.0015(-0.84)$ & $-0.0007(-0.58)$ \\
\hline Adjusted $\mathrm{R}^{2}$ & 0.3619 & 0.3593 \\
\hline $\mathrm{N}$ & 1174 & 1174 \\
\hline
\end{tabular}

t-statistics, in parentheses, are computed using the White (1980) heteroskedasticity-consistent standard error.

$* * *, * *, *$ indicate significance at the $1 \%, 5 \%$, and $10 \%$ levels, respectively. 
Table 7: Regression Estimates of Labor Cost Share

\begin{tabular}{|c|c|}
\hline & $\begin{array}{l}\text { Labor cost to total } \\
\text { operating costs }\end{array}$ \\
\hline Intercept & $0.5773(24.17) * * *$ \\
\hline $\begin{array}{l}\text { Loan Loss Provisions to Total } \\
\text { Loans }\end{array}$ & $-0.1344(-1.90) *$ \\
\hline Cash to Total Assets & $0.1439(1.51)$ \\
\hline Equity to Total Assets & $-0.0067(-0.18)$ \\
\hline Retail Deposits to Total Deposits & $0.0273(2.05) * *$ \\
\hline Loans to Earning Assets & $0.0216(1.11)$ \\
\hline Indonesia & $-0.1400(-15.91) * * *$ \\
\hline South Korea & $-0.1844(-6.46) * * *$ \\
\hline Malaysia & $-0.0648(-8.18) * * *$ \\
\hline Philippines & $-0.2128(-27.18) * * *$ \\
\hline Singapore & $-0.1290(-5.04) * * *$ \\
\hline Thailand & $-0.2180(-15.67) * * *$ \\
\hline 1993 & $-0.0131(-0.96)$ \\
\hline 1994 & $-0.0095(-0.74)$ \\
\hline 1995 & $-0.0146(-1.18)$ \\
\hline 1996 & $-0.0169(-1.41)$ \\
\hline 1997 & $-0.0366(-2.86) * *$ \\
\hline 1998 & $-0.0621(-4.28) * * *$ \\
\hline 1999 & $-0.0506(-3.78) * * *$ \\
\hline Adjusted $\mathrm{R}^{2}$ & 0.4070 \\
\hline $\mathrm{N}$ & 1174 \\
\hline
\end{tabular}

t-statistics, in parentheses, are computed using the White (1980) heteroskedasticity-consistent standard error.

$* * *, * *, *$ indicate significance at the $1 \%, 5 \%$, and $10 \%$ levels, respectively. 
Table 8: Regression Estimates of Labor Cost Share on Wage Rate

\begin{tabular}{|l|c|}
\hline & $\begin{array}{c}\text { Labor cost to total } \\
\text { operating costs }\end{array}$ \\
\hline Intercept & $0.4515(13.24) * * *$ \\
\hline $\begin{array}{l}\text { Loan Loss Provisions to Total } \\
\text { Loans }\end{array}$ & $-0.7361(-3.73) * * *$ \\
\hline Cash to Total Assets & $0.6971(6.15) * * *$ \\
\hline Equity to Total Assets & $-0.3063(-5.19) * * *$ \\
\hline Retail Deposits to Total Deposits & $0.1645(6.85) * * *$ \\
\hline Loans to Earning Assets & $-0.2196(-8.40) * * *$ \\
\hline Average Earnings Per Month & $0.0559(6.34) * * *$ \\
\hline Adjusted R ${ }^{2}$ & 0.31 \\
\hline $\mathrm{N}$ & 681 \\
\hline
\end{tabular}

t-statistics, in parentheses, are computed using the White (1980) heteroskedasticity-consistent standard error.

$* * *, * * *$ indicate significance at the $1 \%, 5 \%$, and $10 \%$ levels, respectively. 
Figure 1: Operating Efficiency and Openness (Commitment)

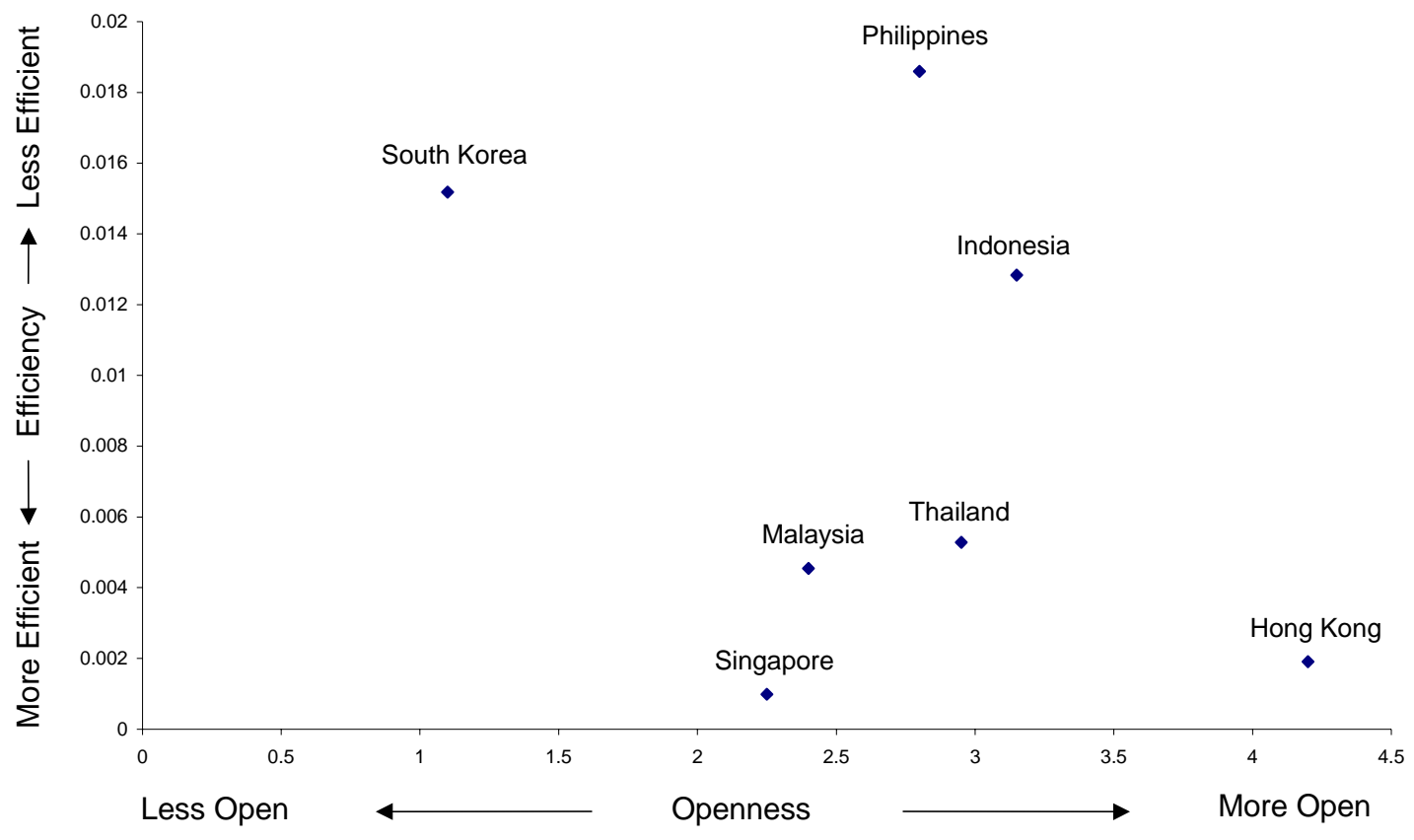

Figure 2: Operating Efficiency and Openness (Practice)

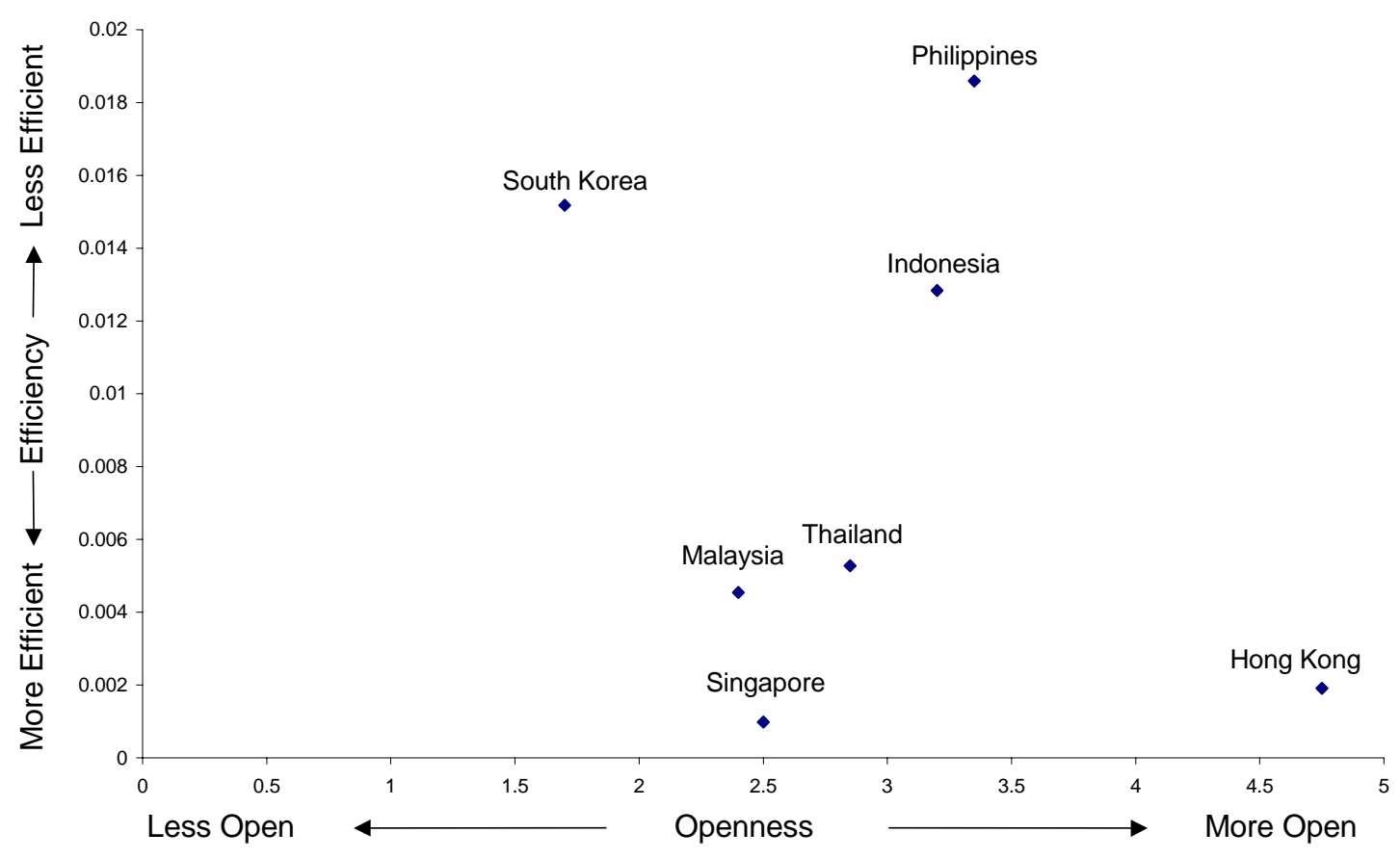

